\title{
Quem ama sofre, quem sofre luta, quem luta vence: da conjugalidade entre travestis e seus maridos
}

\author{
Fernando Seffner \\ Doutor em Educação (Universidade Federal do Rio Grande do Sul) \\ Professor da Universidade Federal do Rio Grande do Sul \\ fernandoseffner@gmail.com \\ Magnor Ido Müller \\ Mestre em Educação (Universidade Federal do Rio Grande do Sul) \\ Pesquisador na Universidade Federal do Rio Grande do Sul \\ magnormuller@terra.com.br
}

\begin{abstract}
Resumo Este estudo, desenvolvido entre os anos 2009 a 2011, buscou conhecer e analisar alguns elementos que organizam a relação de conjugalidade entre as travestis e seus maridos. Durante dois anos, estabeleceu-se um regime de acompanhamento de três casais que vivem na região metropolitana de Porto Alegre, envolvendo entrevistas e observação participante. Foi possível perceber o complexo jogo de adesão e resistência ao modelo heteronormativo de conjugalidade, produzindo uma agonística de forte tensão. Dois elementos se destacam nas estratégias de aliança entre esses casais: certa circulação de atributos de masculinidade e feminilidade entre as travestis e seus maridos e um conjunto de disposições que ordenam a vida sexual, reificando as tradicionais expectativas de gênero e evitando performances que possam lembrar a relação das travestis com seus clientes na prostituição.
\end{abstract}

Palavras-chave: travesti, conjugalidade, relações de gênero, sexualidade, masculinidade.

\section{“Uns por demais, uns masculinos, uns femininos, uns assim..."}

\footnotetext{
AXPressão que intitula este tópico está inspirada na canção Uns

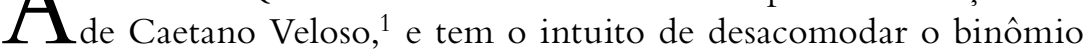
naturalizado "ser homem ou ser mulher". Colocada dessa forma, a frase - e boa parte do restante da canção - pode estimular uma reflexão sobre outras possibilidades de viver a sexualidade, a produção de gêneros, o atravessamento das fronteiras consideradas socialmente como sendo as

1. Essa canção consta originalmente em disco do mesmo nome, Uns (1983) - LP/CD Philips/ Polygram. Também pode ser vista no DVD MTV Ao Vivo Caetano Zii e Zie (Extras - Show Obra em Progresso), 2011. Em alguns outros pontos deste texto nos valemos de pequenos excertos da mesma música.
} 
“corretas". No presente artigo, ${ }^{2}$ estamos interessados na relação agonística ${ }^{3}$ de circulação de atributos de masculinidade e feminilidade nas relações conjugais entre as travestis e seus maridos.

As travestis são personagens de ampla circulação na cultura brasileira. Provocam desde manifestações explícitas de abjeção a manifestações que revelam admiração e encantamento. Vale retomar o significado de "abjeto" em Judith Butler (2002, p. 161): “O abjeto para mim não se restringe de modo algum a sexo e heteronormatividade. Relaciona-se a todo tipo de corpos cujas vidas não são consideradas vidas e cuja materialidade é entendida como não importante." Para muitos, as travestis são personagens caricatas, necessariamente vinculadas à prostituição e à exibição de seus corpos, vivendo nos limites da contravenção. Por muitas razões, e não apenas por questões ligadas a gênero e sexualidade, elas não são "corpos que importam”, não são vidas viáveis. Por outro lado, as travestis são produtos de grande circulação na mídia e no imaginário social, e sua sexualidade exuberante já colocou muitos famosos em situação constrangedora. Como muitas outras figuras situadas em zonas de fronteira, elas provocam um misto de temor e desejo, promessa de grandes prazeres e, ao mesmo tempo, grandes perigos.

A produção acadêmica sobre a travestilidade ${ }^{4}$ e as travestis é abundante, em especial, enfocando a produção corporal, a vida ligada à prostituição e aos agravos de saúde, particularmente Aids e outras doenças sexualmente transmissíveis. Mas alguns trabalhos, embora preocupados com essa dimensão pública da travestilidade, também se debruçam sobre a vida doméstica e conjugal das travestis, seus amores, romances, suas relações de amizade, sua vida de relações, como vemos em Silva (2007), Kulick (2008) e Benedetti (2005). Em nosso acompanhamento de três casais ao longo de dois anos estivemos mais preocupados em saber da "vida de casados", da gestão da casa, das relações de vizinhança, dos ataques de ciúmes, da satisfação (ou não) da vida sexual, das desconfianças, das alegrias domésticas, da compra de um fogão novo, de quem vai ajeitar a casa hoje, de quem vai providenciar a janta, da conta do armazém etc..

No cenário público por onde as travestis transitam, são frequentes as lutas e enfrentamentos. Nos últimos anos, tivemos decisões judiciais a favor de uniões homossexuais, da garantia de uso do nome social, o incremento de legislação que pune a discriminação, as tratativas de exigências de respeito às travestis por parte das forças policiais, a escolha de travestis para integrar conselhos de saúde, segurança, previdência, direitos humanos, as campanhas governamentais de alerta ao uso de silicone seguro. Por outro lado, atos homofóbicos, situações que negam os direitos de cidadãos gays, travestis e transexuais continuam a fazer parte do cotidiano da vida social, de um modo tão rotineiro que aparecem como algo "naturalizado". A dimensão que estivemos investigando, da vida doméstica de algumas travestis com seus maridos, pouco parece se conectar com esse universo político de lutas e reivindicações. Ali, a vida segue quase que outro ritmo, mais relacionado com problemas de outra ordem: finanças, ciúmes, vizinhos, trabalho, lazer.

No desenho inicial, esta pesquisa enfocava exclusivamente a figura do marido da travesti. Logo nos demos conta de que o acesso aos maridos praticamente não podia ser feito sem a forte interferência delas. Depois de muitas visitas, percebemos que o material mais interessante para analisar não eram exatamente as trajetórias dos homens, mas as situações conjugais em que a circulação de atributos de gênero, sexualidade e poder era objeto de frequentes negociações; e fomos então por esse caminho. Passamos a visitar os casais não mais para conversar com os maridos, ${ }^{5}$ mas para conversar com o casal, para saber da vida conjugal, dos laços afetivos. Ao "desnaturalizar" diferentes tipos de aliança, Heilborn problematiza a relação social que constitui a conjugalidade. Segundo o autor,

[... a conjugalidade não emerge de um fato jurídico. É, isto sim, o que expressa uma relação social que condensa um 'estilo de vida', fundado em uma dependência mútua e em uma dada modalidade de

\footnotetext{
2. Este artigo é, em parte, oriundo de material coletado no âmbito da pesquisa que resultou na dissertação de mestrado de Magnor Ido Muller, intitulada Lá em casa a gente conversa! Pedagogias da conjugalidade entre travestis e seus maridos, orientada por Fernando Seffner e defendida em 2011 no Programa de Pós-Graduação em Educação da UFRGS.
}

3. Utilizamos o substantivo agonística para colocar em destaque, nessas relações entre as travestis e seus maridos, um conjunto de técnicas argumentativas que evocam a prática de combates e lutas corporais, e que denotam excepcional empenho no sentido de fazer valer uma opinião.

4. Seguindo o caminho já trilhado na substituição do termo homossexualismo pelo termo homossexualidade, optamos aqui pelo uso do termo travestilidade, mais vinculado à ideia de uma identidade cultural, ao invés do tradicional travestismo, que nos parece manifestar um aspecto patologizante. Tal discussão pode ser acompanhada em Pelúcio (2008). Ao longo do texto, nos referimos às travestis como pertencentes ao gênero feminino.

5. Marido é o termo êmico utilizado pelas travestis para definir o homem que tem uma relação estável e mora com elas. O termo é amplamente utilizado durante conversas entre elas ou com pessoas de sua rede de sociabilidade e, com frequência, elas se valem de estratégias para diferenciar os maridos dos clientes. O que não elimina a possibilidade de que, por vezes, elas provoquem os maridos, relatando gestos de generosidade e afeto dos clientes. 
arranjo cotidiano, mais do que propriamente doméstico, considerando-se que a coabitação não é regra necessária. (Heilborn, 2004, p. 11-12)

O trabalho doméstico, o cuidado da relação, o nexo amizade e sexo e a gramática da cópula são os princípios norteadores da vida conjugal. As visitas, conversas e entrevistas nos permitiram investigar o convívio do casal, a rotina dos afazeres domésticos e a distribuição das tarefas no cotidiano. A partir das análises de seus depoimentos, apresentamos e discutimos as dinâmicas e os movimentos que se estabelecem na relação entre marido e mulher e as relações sociais no local onde residem. Interessa-nos perceber o complexo jogo de adesão e resistência ao modelo de conjugalidade hegemônico que está instaurado na aliança entre esses casais.

\section{“Uns andam, uns avançam": nosso caminho}

A pesquisa que deu origem a este texto implicou transitar na intimidade dos casais e exigiu dedicação e tempo para construir e manter vínculo com os envolvidos. O trabalho só pôde ser realizado, porque os pesquisadores já haviam trilhado largo caminho junto às travestis e suas organizações, tanto na reflexão acadêmica (Muller, 2007, 2009 e Seffner, 2008, 2011, 2011a) quanto no acompanhamento das ações militantes e de luta contra a Aids desse grupo. Em campo, deparamo-nos com duas situações bastante distintas e de funcionamento "complementar": a fala "excessiva" das travestis e o "retraimento" dos seus maridos. Ainda que perguntas fossem direcionadas ao marido, muitas respostas se restringiam a "sim" e "não". Os maridos com quem tivemos contato são em geral mais calados, observadores, parecem bastante introspectivos. Na relação com as travestis, em diversos momentos, quando estão falando, são "cortados" por elas que inclusive "desmentem" o que eles estavam afirmando.

Mas essa situação logo foi revertida, e foi possível manter uma conversa sobre o relacionamento do casal sem maiores constrangimentos. Os homens, inclusive, aproveitaram a presença dos pesquisadores para levantar pequenas "queixas" sobre elas, em especial, relativas às cenas de ciúme. Dessa forma, as situações que apresentamos a seguir são fruto de uma estratégia metodológica que se poderia situar entre a conversa em pequeno grupo e a entrevista. Em alguns momentos, fizemos perguntas e essas foram diretamente respondidas. Em outros, a conversa seguiu rumos cada vez mais imprevisíveis, e apareceram informa- ções sobre a rede de relações, os problemas cotidianos, o modo como os dois se conheceram, os planos futuros. Estar na casa dos entrevistados permitiu também conhecer os ambientes, a disposição dos móveis, a organização da casa, o trato com os vizinhos. Apesar da informalidade, utilizamos termos de consentimento, livre e esclarecido em todas as abordagens, e ficou sempre muito claro que estávamos interessados em pesquisar aspectos da vida do casal, o que não pareceu trazer constrangimentos nem aos maridos e muito menos às travestis. A garantia de sigilo, sempre enfatizada por nós, certamente foi importante, mas percebemos que os casais não demonstravam grande preocupação em revelar suas rotinas e "segredos", o que, em parte, pode ser explicado pelo fato de que as famílias sabem de sua relação, bem como vizinhos e, por vezes, até mesmo colegas de trabalho do marido.

Além do que foi colhido na relação com os três casais, a inserção do pesquisador principal em outras redes de relações e ativismo político permitiu colher outras impressões sobre o tema "maridos", expressadas por outras travestis, e que foram incorporadas no diário de campo. Quanto à utilização de mais de uma técnica de pesquisa, acompanhamos Víctora (2000, p. 61): "O uso de técnicas combinadas, isso é, a utilização coerente de mais de uma técnica, permite suprir lacunas e tornar mais completa a coleta de informações em campo". Na mesma direção sobre a escolha do método, nos alinhamos com Geertz:

[...] Segundo a opinião dos livros-textos, praticar a etnografia é estabelecer relações, selecionar informantes, transcrever textos, levantar genealogias, mapear campos, manter um diário, e assim por diante. Mas não são essas coisas, as técnicas e os processos determinados, que definem o empreendimento. $\mathrm{O}$ que define é o tipo de esforço intelectual que ele representa: um risco elaborado para uma "descrição densa", tomando emprestada uma noção de Gilbert Ryle. (Geertz, 1989, p. 4)

Esta pesquisa não guarda nenhuma preocupação em se apresentar como imparcial ou neutra. Ao contrário, ela é fruto de um envolvimento com os participantes, o que permitiu, inclusive, transitar na intimidade de suas casas; a aproximação, o vínculo formado entre pesquisador e pesquisado, antes de se apresentar como um "problema", representou condição sine qua non para a realização do estudo. Mais ainda, permitiu ultrapassar a dicotomia "pesquisador/pesquisado", e apresentar os casais como colaboradores, em particular, porque eles não se comportaram apenas como "informantes", mas ativamente colaboraram nas conversas para refletir sobre seu relacionamento, o que nos parece, até mesmo, ter sido vivenciado por eles como um "ganho" através desta pesquisa. 


\section{"Uns dizem fim, uns dizem sim, e não há outros": quem são os casais}

No contato com organizações de travestis em Porto Alegre, o pesquisador principal teve conhecimento de muitos casais. Entretanto, decidiu-se utilizar a técnica de snowball, ou seja, os participantes indicam novos informantes para fazerem parte da pesquisa. Assim, a partir do primeiro, chegamos ao segundo e ao terceiro casais. Ademais, os casais mantêm relações entre si, o que favoreceu os contatos.

O primeiro casal visitado é formado por Magda (52 anos) e Pedro (26 anos), ${ }^{6}$ que haviam se mudado recentemente para uma casa nos fundos do segundo casal, Sibele e Gustavo. Habitação pequena, quarto, cozinha/sala e banheiro, tanque para lavagem de roupas nos fundos, escasso mobiliário. A primeira conversa transcorreu no quarto do casal, sentados alguns na cama e outros em cadeiras, pois estavam em fase de arrumação do espaço. Já na segunda visita, eles haviam se transferido para a casa onde, antes, habitavam Sibele e Gustavo que, por sua vez, tinham passado a outra, na mesma rua, exatamente em frente, mantendo a relação de vizinhança. Costumeiramente, a partir da segunda visita, em um total de dez encontros, Magda e Pedro recebiam o pesquisador como amigo, mostrando as novas aquisições, e insistindo para que tomasse liberdades, como abrir a geladeira para beber alguma coisa. Em determinado período, o irmão de Pedro, que estivera encarcerado por sete anos e que em 2010 fora libertado, morou com o casal. Dormia no sofá da sala e, às vezes, passava uma "temporada" na casa de outra travesti a qual, segundo Magda, tinha um relacionamento com ele. O casal preza pelo asseio e a organização da casa.

Sibele (25 anos) e Gustavo (38 anos) já foram visitados na casa nova, de madeira, bem pintada, que possui cinco cômodos. Entre a rua e a casa há uma área coberta, com mesa, cadeiras, churrasqueira e o varal. Na lateral esquerda, um corredor acompanha a extensão da casa e termina em outro acesso, em que se entra diretamente na cozinha. As janelas da sala e do quarto de casal dão para a rua. $O$ segundo quarto estava alugado para Andressa (25 anos), travesti amiga de Sibele. Ao dar guarida à outra travesti, Sibele, em certa medida, cria uma relação de proteção mútua, uma vez que sua inquilina não divide apenas as despesas da casa, mas lhe faz companhia; juntas se preparam para o trabalho, tomam a condução, uma em companhia da outra, até o local da "batalha", dividem segredos e cumplicidades. Lembramos que elas atuam no mercado da prostituição, em avenida de acesso à cidade de Porto Alegre, bastante longe do local de moradia.
O terceiro casal é composto por Franciele (22 anos) e Jonatan (24 anos), que residem em local distante dos outros dois casais. A casa fica nos fundos de outra e em frente a uma terceira, ou seja, no mesmo terreno há três casas. Na primeira mora a dona do terreno e das casas, e o outro vizinho é pessoa desconhecida do casal. A casa é composta por três cômodos: o quarto de casal, uma peça para cozinha e sala, e o banheiro. O espaço é acanhado, e foi com bom humor que explicaram que a motocicleta de Jonatan é guardada dentro de casa à noite, o que implica dizer que ela fica no quarto de casal, ao lado da cama. Completadas as descrições das casas, nos parece oportuno refletir sobre o impacto que elas podem causar, especialmente quando conectadas a valores morais:

[...] Num primeiro contato, a pobreza nos parece desordenada: ruas mal traçadas, barracos construídos muito próximos uns dos outros (o que também ocorre com as casas populares), cômodos contíguos, praticamente sem separações internas, tudo isso pode, facilmente, ser relacionado a uma confusão moral. (TAUBE, 1992, p. 29)

Ao investigar as formas de moradia dos casais das camadas populares, a autora expõe o quanto o pensamento das classes mais favorecidas vincula a precariedade do espaço social em que habitam as populações carentes com uma "confusão moral", uma incapacidade de gerenciar suas relações sociais e afetivas. Talvez para mostrar oposição a isso, as três casas primam pela limpeza e organização, quase ao ponto de que nos obrigarmos, algumas vezes, a comentar como estava tudo limpo e bem disposto, inclusive no pátio e na área dos fundos. Podemos pensar na ideia de luta contra a confusão, manifestada na ênfase em colocar tudo no seu devido lugar dentro de casa.

Para além dos casais diretamente entrevistados, verificamos que ter outras travestis, solteiras ou casadas, morando nos arredores de suas casas é uma prática comum entre elas. Quando uma travesti ou um casal muda de local, inicia-se uma série de contatos entre suas amigas, a fim de ver as possibilidades de aquele espaço ser ocupado por outros casais ou por travestis solteiras que desejam mudar ou dividir com mais uma o mesmo teto. Vale dizer que não são todos os proprietários de imóveis que aceitam alugar para travestis suas casas e, por vezes, aquela que já reside no bairro indica ao proprietário outra travesti para o imóvel vago. Os maridos não parecem participar dessas negociações, assistindo a tudo com alguma indiferença, não dando opiniões e nem mesmo sendo chamados a opinar. As tratativas quanto ao local de moradia parecem ser uma coisa "delas", conforme o comentário "deles". Alugada a nova moradia, os ma- 
ridos entram em cena, por conta dos acertos da mudança e da instalação.

As travestis com quem convivemos salientaram que a indicação de companheiras para ocupar imóveis do mesmo proprietário de suas casas é estratégia rigorosamente restrita a amigas em quem confiam e que cumprirão com o pagamento exigido. Os deslizes no pagamento do aluguel - que geraram queixas do dono do imóvel para a travesti que indicou a outra - foram descritos com um sentimento de "traição", implicando descrédito na amizade e, por vezes, culminando com o rompimento da relação entre elas. As visitas e observações permitiram presenciar comentários bastante cruéis em relação àquelas que "não cumpriram com a palavra", decepcionando tanto o proprietário da habitação quanto a travesti que serviu como "fiadora". A má pagadora certamente encontrará dificuldade para encontrar um lugar para morar nas proximidades. Diante dessas situações, a "excluída" acionará outras amizades até conhecer um proprietário que lhe dê "crédito". O pagamento "sem atraso" do aluguel e de prestações de bens materiais nos pareceu fundamental na vida dos casais com quem conversamos. Ter as contas pagas pontualmente significa um atestado de "honestidade e caráter". Não são medidos esforços para isso. Verificamos, inclusive, certas situações em que a aquisição de artigos de higiene e, até mesmo, a alimentação foram deixados em segundo plano, a fim de terem "as contas em dia". Essa prática parece agregar "prestígio" ao casal nas suas redes de sociabilidade. Por vezes, isso foi motivo de discussões entre a travesti e seu marido, e escutamos críticas tanto da travesti em relação a gastos desnecessários do marido, quanto deste em relação a gastos desnecessários dela. Novamente reiteramos os três verbos presentes no título deste artigo: sofrer, lutar, vencer, a serviço do amor conjugal.

As travestis visitadas apresentam forte investimento na produção corporal, apesar das diferenças de idade entre elas. Conforme já analisado por outros autores, é no corpo que as travestis "atravessam" as fronteiras de masculino e feminino. Entre os métodos utilizados estão: adoção de um nome feminino, a transformação do corpo a partir do uso de hormônios femininos e da aplicação de silicone, produzindo curvas em geral avantajadas, a eliminação das atitudes masculinizadas e o cuidado com o vestuário, favorecendo a expressão da sensualidade. As travestis realizam, dessa forma, um grande investimento que não é apenas econômico, mas também emocional e social. Segundo Benedetti:

As travestis, ao investir tempo, dinheiro e emoção nos processos de alteração corporal, não estão concebendo o corpo como um mero suporte de significados. O corpo das travestis é, sobretudo, uma linguagem; é no corpo e por meio dele que os significados do feminino e do masculino se concretizam e conferem à pessoa suas qualidades sociais. É no corpo que as travestis se produzem enquanto sujeitos. (Benedetti, 2005 , p. 55)

O "investimento" referido pelo autor foi tema de várias conversas delas conosco, e é valorizado pelos maridos. Esse feminino construído e constantemente aperfeiçoado atravessa as relações conjugais e, certamente, não se faz apenas para agradar aos clientes da prostituição. Ele guarda estreita relação com a masculinidade dos seus maridos, que é algo "dado", não precisa ser "aperfeiçoado", apenas "demonstrado". Uma parte dos esforços na produção do corpo e das atitudes femininas serve para delimitar a relação entre os gêneros, pois quanto mais femininas, mais são "mulheres", e mais os companheiros aparecem como "verdadeiros" maridos. Em casa elas não estavam "espetaculares" como se apresentam na "batalha”, pois ali não se tratava de atrair clientes. Em casa elas estavam vestidas de modo feminino, e até recatado, garantindo aos maridos sua versão de "esposas". Pelo menos, até o final da tarde, quando se produziam para sair para a "batalha". Nesse sentido Larissa Pelúcio escreve:

Essa dimensão interna, expressa no sentir-se mulher ("sinto dentro de mim"), aparece na fala de muitas travestis na locução "ter cabeça de mulher”. Uma interioridade que precisa ser externalizada na materialidade do corpo, compondo uma totalidade, que faz do corpo sexualizado o locus da produção de uma identidade que, mesmo fluida, se alicerça num sistema simbólico no qual as representações de gênero, sexualidade e corporalidade são categorias estruturantes e mutuamente referentes. Um gênero que pode ser transformado a fim de adequar o desejo - e, assim, a sexualidade - a valores morais que fixam papéis e prescrevem comportamentos cabíveis ao feminino. (Pelúcio, 2009, p. 227)

A autora salienta o simbolismo que os atributos femininos darão para o corpo e que o farão ser "interpretado" como um corpo "de mulher", exteriorizando, dessa maneira, o sentimento de "sentir dentro de mim”. Observa-se, também, um esforço para inserir o corpo de esposa no padrão heteronormativo, fugindo da ideia de que elas seriam "exóticas", como por vezes se apresentam nos locais de prostituição (usando véus, roupas mínimas, saltos enormes, cabelos coloridos etc.).

Os maridos que participaram desta pesquisa não parecem fugir dos atributos de masculinidade hegemônica. Assumem-se heterossexuais, desejam uma parceira para compor um núcleo familiar, buscam 
adaptar sua forma de conjugalidade aos pressupostos heteronormativos e referem seu desejo de possuírem a condição de "provedores do lar". Entretanto, os três maridos, na época de nosso convívio com os casais, não estavam em situação de assumir completamente a função de provedores do lar. Isso ocorria não apenas por não terem ganhos compatíveis com o das companheiras, mas porque a agilidade delas - em negociar o local de moradia, a compra dos móveis, o ingresso de alguma companheira para dividir despesas, o planejamento do futuro, as diretrizes da relação com os vizinhos etc. - fazia com que o gerenciamento financeiro do casal estivesse nas mãos das esposas. Conforme já observado em Kulick (2008) e Benedetti (2005), parece-nos que o modelo hegemônico de masculinidade, no qual o homem deve ser o provedor do lar, é um componente muito mais da retórica desses maridos do que propriamente da vivência conjugal. Ainda que, na rotina dos casais que participaram do estudo, todos os maridos trabalhem, ${ }^{7}$ a remuneração não é utilizada para fazer frente às despesas da casa e possibilitar, com isso, que suas esposas abandonem a prostituição nas ruas. Mais ainda, na história dos relacionamentos estudados aqui, quem enfrentou constantes períodos de desemprego, baixa remuneração ou vinculação trabalhista precária foram os homens, enquanto as travestis se mantiveram sempre com regularidade de proventos, mesmo em períodos turbulentos.

\section{"Uns mal, uns bem, uns nada além": cenas e histórias}

Ao iniciarmos as visitas aos três casais, tínhamos em mente que as questões da vida sexual não seriam o assunto das primeiras conversas, ficando reservadas para um momento futuro. Um tanto surpresos, verificamos que logo nos primeiros encontros esse tema já dominava parte das conversas, envolvendo inclusive os maridos, em geral mais reservados. Analisando "a posteriori" a dinâmica desses encontros iniciais, percebemos que informantes e pesquisadores se envolveram em um jogo de expectativas mútuas. Os casais concluíram, desde logo, que era da intimidade de sua vida sexual que mais gostaríamos de obter informações. Os pesquisadores construíram um roteiro de abordagem que contemplava muitas outras questões, mas depois, examinando todo o processo, nos demos conta que estávamos também capturados pelo desejo de saber sobre o sexo e que as demais questões eram apenas uma "escada" para chegarmos, em al- gum momento, à dinâmica da vida sexual. Avaliando retroativamente, verificamos que a primeira entrevista feita, com Magda e Pedro, já acontecera logo no quarto, conforme acima comentado, por falta de cadeiras na casa, o que é agora interpretado por nós como um sugestivo sinal.

Em uma visita a Sibele e Gustavo, Andressa, que ocupa um quarto da casa, abordou diretamente seu desânimo em relação aos casamentos em que já estivera envolvida, especialmente por conta do regramento que visa resguardar a conjugalidade das relações, da "perversidade" do que é feito com os clientes:

Ao questionar Andressa sobre por que ela não tem mais interesse em se casar, surpreendi-me com a resposta. Segundo ela, os maridos, após um tempo de relação, iniciam com prática de sexo oral na travesti e depois terminam por tornarem-se passivos na relação sexual. Essa atitude provoca na travesti uma decepção, pois elas procuram o homem viril, macho, ativo sexualmente. Por conta disso, ela anda desiludida dos casamentos. (Diário de campo)

Essa situação coloca o marido em pé de igualdade com os clientes, provocando erosão nas expectativas do que deve ser um "verdadeiro marido". Um dos requisitos fundamentais do marido (e da manutenção da relação conjugal) é, pois, a garantia do desempenho ativo, reforçando nelas sua feminilidade e nos possibilitando concluir quão importantes são as fronteiras de gênero nessas relações. $\mathrm{O}$ assunto foi amplamente abordado em uma das conversas gravadas com o casal Magda e Pedro. Inicialmente, a conversa ocorreu quando Pedro estava fora:

Pesquisador: [...] um dia, a gente conversando, e eu lembro que tava a Sibele e a Franciele junto, que a gente falou da questão que um dos critérios que a travesti leva muito em conta para ter um marido é que ele não pegue no pênis dela, né, isso é uma coisa importante, que ele não toque ela. Eu lembro que naquela época eu perguntei: "Tá, mas como é que ele vai beijar o seio de vocês, como é que ele vai deitar em cima de vocês, se ele não vai poder encostar?”. Aí tu disseste: "Ah, isso a gente dá um jeito de ladinho, a gente faz um truque, pra ele não encostar e tal". E no caso beijo, funcionaria da mesma forma?

Magda: Com certeza.

Pesquisador: $\mathrm{O}$ beijo vai ser de lado também? Magda: Não, não, a gente vai dar o beijo de frente, mas é aquela coisa assim ó, eu, por exemplo, assim ó... (Mostra com o corpo que a cabeça se projeta em direção ao companheiro, enquanto a pélvis fica um tanto recuada).

Pesquisador: Mas assim, por exemplo, você não daria o beijo sem calcinha, tu ficarias com calcinha? 
Magda: Não, não... Vestida, vestida... No meu caso, com o Pedro, a gente tá há dez anos e comigo ele sempre foi totalmente ativo. Não sei se, de repente, num outro relacionamento dele, homossexuais, né, teve outras formas ou maneiras de orgasmos, entendeu? Mas, particularmente comigo, ele sempre foi ativo, acho que é por isso que eu tô com ele até hoje, eu sou totalmente passiva com ele, totalmente feminina, né. Porque a minha cabeça, eu construí essa forma, essa maneira. (Entrevista com Magda em 8.4.2011)

Sobre o tema, Pedro comentou no encontro seguinte:

Pedro: Eu peço pra ela (Magda) sempre ficar de costas pra mim, eu não pego no pênis, no máximo que eu passo a mão é na barriga e do umbigo pra cima. (Sobre a possibilidade de ser passivo na relação sexual.) Nunca na minha vida até hoje, desde guri de programa; eu já perdi dinheiro de muitos clientes, que até hoje os guri me falam, já perdi de ganhar dinheiro alto. Numa época até, nessa questão, já perdi uma vez de ter ganhado uma bolada, que podia estar até hoje bem, eu disse não. Não vou fazer isso que logo, mais cedo ou mais tarde, eu posso me arrepender. Essa questão da cama mesmo, sempre fui ativo.

Pesquisador: Mas vocês se beijam?

Pedro: Normal.

Pesquisador: Sim, mas quando tu vai beijar uma pessoa, tu fica de frente pra ela, vocês se beijam assim? Pedro: Nós nos beijamos de frente.

Pesquisador: Mas aí tu não encostas muito no corpo?

Pedro: Encosto.

Pesquisador: Mas aí tu não vai sentir?

Pedro: Ah, vai de pessoa pra pessoa, ela não demonstra muito. Ela não demonstra naquela hora ali do toque. Tem muitas pessoas que já demonstram na hora do toque ali, ela já não demonstra nessa parte. Nessa questão eu evito tocar, pra não... para não me sentir mal. (Entrevista com Pedro em 9.4.2011)

Na sequência da conversa, e com muito bom humor da parte dos dois, o significado do verbo "demonstrar" foi devidamente esclarecido. Magda era elogiada pelo marido, porque não demonstrava excitação no pênis e, por conta disso, não havia risco de beijar de frente, encostando os corpos. Esse detalhe era garantia da feminilidade de Magda, permitia uma performance perfeitamente ajustada ao que se espera de um casal "normal", homem e mulher, e aquilo "que se vê nos filmes românticos, com beijos de frente, corpos unidos". Em muitas outras conversas, foi possível perceber que partes do corpo são preservadas, partes do corpo são proibidas, algumas posi- ções são consideradas mais adequadas do que outras, configurando um regramento que preserva tradicionais expectativas de gênero. Na conversa de Pedro, destacamos uma ênfase presente também na fala dos outros maridos: eles nunca desempenharam papéis passivos nas relações sexuais. E a solidez dessa opção fica reforçada pela narrativa de propostas financeiras elevadas que foram rejeitadas. A esse respeito, Jonatan assim se expressou em uma das entrevistas: "Eu podia ser um guri novo com casa montada e carro na garagem, se aceitasse ser passivo, mas isso eu não faço de jeito nenhum; não é minha praia e não admito discussão, e ela sabe disso muito bem (referindo-se a Franciele)". São aspectos de renúncia, de luta e de vitória, insistentemente enaltecidos nas trajetórias de vida, e que garantem uma masculinidade à sombra de qualquer dúvida.

Esses mesmos aspectos aparecem em dois outros temas: o "empenho salvacionista" das travestis sobre os maridos e as cenas de ciúme. Nas conversas e entrevistas, as travestis repetiram expressões como "eu salvei ele", "eu fiz ele mudar", "hoje ele é outra pessoa", "ele tava jurado de morte e eu salvei ele", "a mãe dele me agradece até hoje pelo que eu livrei ele das drogas". Elas faziam questão de acentuar como eram responsáveis por modificações no modo de vida dos maridos, e tinham deles a concordância explícita com esse ponto de vista. As travestis buscavam deixar claro que no início da relação os maridos eram homens até "desprezados", e que não podiam ser considerados "homens para se trazer para dentro de casa". Essa característica "redentora" que as travestis têm para com seus maridos pode ser observada través do relato de Franciele:

[...] Porque a pessoa que tu gosta, que tu viste se superar, se sobressair, porque eu vejo os amigos dele hoje, os amigos dele estão uma carcaça, drogadíssimos; alguns andam que nem mendigo, que um dia eu olhei para ele e falei "presta atenção, hoje tu vai sair comigo", porque ele estava reclamando da vida, "então, eu vou te levar pra boate e tu vai olhar pros teus amigos e ver como estão e depois vai chegar em casa e olhar como tu estás". Porque na época que eu namorava ele os amigos diziam: "Ah, porque é travesti, porque isso, porque aquilo, entendeste?

$\mathrm{Na}$ conversa, Jonatan concordou de modo claro com o relato da esposa, visto como "prova de amor". Mas, em seguida, passou a enfatizar que ele tinha "força suficiente para se manter no bom caminho" e que se hoje ele estava bem, era porque "tinha decidido se regenerar", e isso havia coincidido com o momento em que encontrara Franciele. Cruzam-se aqui aspectos tensos de gênero, pois tanto é importante reconhecer a dedicação da companheira, quan- 
to é importante não se colocar em situação de ser por ela "governado". Que a companheira gostasse dele ao ponto de investir toda essa energia era um sinal positivo de sua masculinidade, mas, ao mesmo tempo, certa ênfase no "poder" dela em mudar sua vida implicava diminuição de seus atributos masculinos. Temos aqui, novamente, a manifestação dessa estratégia agonística intensa no relacionamento dos casais e que apareceu em muitos momentos.

Em outro diálogo, Pedro, que é nascido no interior do Estado de Santa Catarina, estava contando de sua vinda para Porto Alegre, supostamente em busca de melhores oportunidades de emprego. Magda escutava calada, até o momento em que entrou de súbito na conversa, para acentuar um elemento até ali ausente: "Ele veio para cá, porque estava jurado de morte lá, metido com traficantes, com dívidas; até hoje a mãe dele me agradece porque eu salvei ele disso tudo, essa que é a verdade; o irmão dele passou anos no presídio". Pedro ficou visivelmente constrangido com esse aparte, mas claramente concordou que estava "complicado" por lá e que tinha decidido mudar de região.

Esse discurso "salvacionista" valoriza a travesti frente à família do marido e estabelece um nível de compromisso na relação conjugal que articula passado, presente e futuro, na medida em que ficam superdimensionados os benefícios da relação para o marido. Ele também serve para "mostrar" aos maridos que "outras mulheres" não teriam "força" suficiente para efetuar essas melhorias na vida deles, o que reforça os laços conjugais. Os elementos de sofrimento, de luta e vitória ficam sempre em evidência, apresentando as relações em um equilíbrio de forças poderoso, fato que combina bem com brigas, explosões de cólera, cobranças mútuas.

O ciúme também tem valor tanto "positivo" quanto "negativo" na fala dos maridos. É possível afirmar que a conjugalidade dos pares é intensamente permeada pelo ciúme, o que, por vezes, se constitui em grande obstáculo para a estabilidade da união. Ao mesmo tempo, ele parece ser um importante marcador como expressão do afeto entre ambos. Pedro relatou cenas de ciúme de Magda em uma pizzaria, quando estavam junto com outros casais e, ao mesmo tempo em que reclamava dessas atitudes dela, mantinha nos lábios um sorriso de satisfação, concluindo a queixa com a frase dita em tom quase de alegria: "Ela é doente de ciúme por mim". Magda em seguida disse:

[...] agora, de um tempo pra cá, no decorrer da nossa relação, no tempo que a gente tá junto, o Pedro começou a manifestar o ciúme dele. Ele nunca manifestava, tá entendendo? Agora que eu comecei a sentir. Até na forma, na maneira como eu me visto... On- tem, por exemplo, eu ia sair à noite e ele disse: "Ah, mas tu vai sair com esse vestido?". Eu respondi: "Por que eu não vou sair com esse vestido? Ele não está curtinho." É um vestidinho que eu tenho [...] até eu acho ele um pouquinho mais compridinho. Então, são coisas minúsculas assim, que eu sinto que ele tá se importando, que ele tá falando, que ele tá tocando no assunto. Ele não tocava nesse assunto, no meu modo de vestir, no horário de eu sair.

Para os três casais, nas oportunidades em que saem de casa no intuito de se divertirem, uma pré-condição importante é a escolha de locais onde não estejam outras travestis, para se evitarem as cenas de ciúmes, em especial porque os três maridos já mantiveram outras relações com travestis. Mas esse propósito é difícil de cumprir, uma vez que suas redes de relações são compostas basicamente por travestis, o que restringe os locais de diversão, em especial as boates. Dessa forma, mesmo reconhecendo a possibilidade de problemas, muitas vezes relataram que saíam para dançar em boates e bares com forte presença de travestis. Nesses ambientes, todas estão sempre "atualizadas" sobre "quem casou", "com quem a fulana está", "quem se separou", "quem traiu quem", além de "vigiarem" o comportamento dos homens que estão comprometidos com alguma travesti do seu ciclo de amizade.

O ciúme também pode se manifestar da parte dos maridos por conta das relações das travestis com os clientes. Perguntados acerca disso, os três maridos disseram que não sentiam ciúmes do assédio dos clientes sobre as esposas. Por outro lado, as três travestis foram unânimes em dizer que procuravam não comentar nada acerca das relações com os clientes dentro de casa, para não provocar o ciúme dos maridos. Uma situação visível dessa tensão aconteceu quando clientes telefonaram para elas em momentos em que estavam com os maridos e conosco, o que as obrigou a irem atender o celular no pátio da casa, de modo mais discreto, causando aborrecimento evidente nos maridos.

\section{"Uns dizem fim"}

Recuperando alguns elementos para finalização do texto, queremos ressaltar o conjunto de estratégias postas em ação no sentido de garantir o "lugar" que um "homem de verdade" ocupa nas relações conjugais das travestis. Em torno do marido são acionados mecanismos e estratégias de vigilância, controle, relações de poder que, muitas vezes, promovem a circulação de atributos masculinos e femininos entre o casal. A travesti "batalha" na noite, enquanto seu 
marido é estoquista em um supermercado. Ela se arrisca e enfrenta a polícia, enquanto seu marido, que retornou do serviço, está dormindo. Por outro lado, ao sair da delegacia no meio da madrugada, ela tem um marido a esperando, que a acolhe e leva para casa, no táxi que será pago por ela. O marido acolhedor é visto como um diferencial positivo frente às outras travestis que retornam sozinhas para suas casas.

O convívio com os casais mostrou que eles constroem sua conjugalidade tendo o modelo heteronormativo como alicerce, mas sujeito a numerosas tensões. Quando uma travesti decide estabelecer uma relação conjugal com um homem (porque a iniciativa é normalmente dela, que "aceita" e "providencia" a instalação do marido em um local adequado, como nos foi dito claramente por elas de mais de uma for$\mathrm{ma})$, poder-se-ia imaginar que esse relacionamento "romperia" com o padrão hegemônico. Ao contrário do que supõe o senso comum, essa união não será pautada pela busca de "transgressões". Ali identificamos marcas heteronormativas bem conhecidas: o ciúme, o ideal do amor romântico, a expectativa de que o homem seja o provedor do lar, o comportamento recatado da esposa dentro de casa, os esforços para desenvolver uma boa vizinhança, a vida sexual "normal" e sem "perversões".

Mas esse ideal romântico é atravessado por outros tensionamentos que desestabilizam os roteiros tão valorizados, implicando uma agonística evidente. Há rupturas e continuidades, um pouco ao modo do que ocorre em outras relações, um pouco intensificado pelo atravessamento de fronteiras que caracteriza a construção cultural da travestilidade. A agressão física partindo da travesti sem o revide do marido dá mostras dessa singularidade, como em uma cena da vida de Magda, anotada no diário de campo: "Ela pegou-o pelas orelhas, bateu a cabeça dele na parede e depois jogou um cinzeiro no seu pé. Conforme me disse, quando viu o sangue dele correr se sentiu aliviada, maquiou-se e foi trabalhar." Com variações, encontramos na conversa com os casais e as travestis o uso da frase "Lá em casa a gente conversa", dita por elas a seus maridos, quando não queriam discutir com eles na frente das suas amigas. A frase, no tom em que fora dita, trazia uma promessa de "ameaça", que foi confirmada por alguns maridos, referindo que, ao entrar em casa, elas se mostravam furiosas e faziam cenas de ciúmes que, por vezes, derivavam para a agressão física ou a quebra de objetos dentro do lar.

Essas relações demonstram-se permeadas por grande intensidade e pela vivência de situações extremas, em uma modalidade que estamos qualificando de agonística, o que tanto contribui para desestabilizar a relação quanto, paradoxalmente, contribui para estreitar os laços. Isso porque tais situações reiteram padrões de conjugalidade, atravessados por juras de amor constantes, pela narrativa de uma dedicação sem limites a eles que retribuem, mostrando o quanto se esforçam por atender às demandas delas, até mesmo restringindo a circulação fora de casa, como comentado pelos maridos: "ela me isola, ela me prende em casa"; "ela aproveitou que eu tinha saído do presídio e estava sem os papéis, e me fez ficar em casa um mês sem sair para a rua"; "eu não posso nem cumprimentar uma amiga dela que a casa cai". Essas frases são ditas em tom de queixa, mas nelas é indisfarçável o orgulho de terem ao seu lado alguém tão intensamente apaixonada por eles. No limite, deixar os maridos "presos" em casa impede que eles possam trabalhar. Com isso, o ideal de um provedor fica inviabilizado. Quando Pedro conseguiu emprego de segurança, Magda ficou orgulhosa, e ele vestiu o uniforme novo, quando da visita do pesquisador, mostrando como ficava elegante e atraente com aquela farda. Magda já foi logo comentando que ele nem pensasse em aparecer na frente das suas amigas com aquela farda, e que agora ela ia redobrar a vigilância sobre ele. No dizer dela, quando ele estava em casa desempregado era mais fácil; ela telefonava e ele estava ali, e ela avisava que estava chegando e ele deixava a janta pronta. Ter seu marido desempenhando uma função com marca tão masculina como vigilante era intensamente valorizado e intensamente preocupante, já fazendo antever nova rodada de cenas de ciúmes, o que de fato aconteceu nas semanas seguintes. $\mathrm{O}$ temor da traição é determinante para que as travestis acionem um intrincado sistema de vigilância sobre o comportamento do seu companheiro. A fim de ampliarem o controle, elas envolvem outras pessoas que pertencem à sua rede social. Com isso, por vezes, elas próprias colaboram para que outras travestis se aproximem de seus maridos, potencializando disputas e brigas entre elas.

Por fim, poder-se-ia especular que os homens casados com travestis vivem uma permanente situação de ameaça a sua masculinidade, o que reforça a adesão à demarcação estrita de fronteiras de gênero. Ao mesmo tempo, as travestis talvez sejam fundamentais para que a masculinidade de seus maridos seja compreendida por eles como marcadamente heterossexual, na medida em que suas práticas sexuais e seus critérios de escolha reiteram o modelo hegemônico. Nessa relação, esses homens também afirmam o seu gênero masculino sob a perspectiva social, pois são objeto de ciúmes, são os que penetram, são sempre ativos, e são por elas sustentados financeiramente. Temos aqui outra interface de intenso conflito, entre desconstruir uma possível "imagem" de gigolô que comumente é associada àqueles que se relacionam ou dependem de uma profissional do sexo, e a imagem de marido provedor, que no limite vai lhes "tirar dessa vida", o que é por elas verbalizado como desejo, mas que parece nunca ocorrer. A mesma travesti que insiste em 
nos dizer que seu marido está arrumando os dentes para conseguir um emprego melhor e assumir todas as despesas da casa, em seguida confessa que não se imagina vivendo eternamente como dona de casa, em frases assim: "Depois de um tempo na batalha, a gente vicia naquilo. Deus me livre ficar só dentro de casa; eu quero desfilar na calçada, aquele monte de caminhoneiro me assobiando".

\title{
Referências
}

BENEDETTI, Marcos. Toda feita: o corpo e o gênero das travestis. Rio de Janeiro: Garamond, 2005.

BUTLER, Judith. Como os corpos se tornam matéria: entrevista com Judith Butler. Revista Estudos Feministas, São Paulo, n. 1, p. 155-167, 2002.

GEERTZ, Clifford. A interpretação das culturas. Rio de Janeiro: LTC Editora, 1989.

HEILBORN, Maria Luiza. Dois é par: gênero e identidade sexual em contexto igualitário. Rio de Janeiro: Garamond, 2004.

KULICK, Don. Travesti: prostituição, sexo, gênero e cultura no Brasil. Rio de Janeiro: Fiocruz, 2008.

MÜLLER, Magnor Ido. "É isso aí! Uma mistura dos dois!": a percepção das travestis sobre o seu corpo. Porto Alegre, 2009. Trabalho de conclusão de Especialização (Educação, Sexualidade e Relações de Gênero) - Universidade Federal do Rio Grande do Sul.

MÜLLER, Magnor Ido. Os médicos nunca me tocaram um dedo! E eu cansei daquele Posto: a percepção das travestis quanto ao atendimento público de saúde. Porto Alegre, 2007. Trabalho de conclusão de Especialização (Saúde Pública) - Universidade Federal do Rio Grande do Sul. PELÚCIO, Larissa. Abjeção e desejo: uma etnografia travesti sobre o modelo preventivo de Aids. São Paulo: Annablume, 2009.

PELÚCIO, Larissa. Experiências plurais em categorias singulares: Problematizando a materialização das travestilidades. Texto apresentado no Fazendo Gênero 8, 2008. Disponível em: http://www.fazendogenero.ufsc. br/8/sts/ST61/Silva-Tosta_61.pdf .

SEFFNER, Fernando. Gênero, sexualidade, violência e poder: homens $=$ sexo, violência e poder: dá para mudar esta equação? Salto para o Futuro: educação para a igualdade de gênero. Ano XVIII. Boletim 26. Brasília: Ministério da Educação, nov. 2008.

SEFFNER, Fernando. Identidade de gênero, orientação sexual e vulnerabilidade social: pensando algumas situações brasileiras. In: VENTURI, Gustavo; BOKANY, Vilma (Org.). Diversidade sexual e homofobia no Brasil. São Paulo: Editora Fundação Perseu Abramo, 2011.

SEFFNER, Fernando. Composições (com) e resistências (à) norma: pensando corpo, saúde, políticas e direitos LGBT. In: COLLING, Leandro (Org.). Stonewall $40+o$ que no Brasil? Salvador: EDUFBA, 2011a.

SILVA, Hélio. Travestis: entre o espelho e a rua. Rio de Janeiro: Rocco, 2007.

TAUBE, Maria José de Mattos. Alianças partidas ou a dor da separação conjugal nas camadas populares. In: PORCHAT, Ieda (Org.). Amor, casamento, separação: a falência de um mito. São Paulo: Brasiliense, 1992.

VÍCTORA, Ceres Gomes; KNAUTH, Daniela Riva; HASSEM, Maria de Nazareth. Pesquisa qualitativa em saúde: uma introdução ao tema. Porto Alegre: Tomo Editorial, 2000 .

\section{Those who love, suffer; those who suffer, fight; those who fight, win: conjugality between transvestites and their husbands}

\begin{abstract}
This research was developed between the years of 2009 to 2011. It aimed at knowing how to build a conjugal relationship between transvestites and their husbands. During two years, three couples living in the metropolitan area of Porto Alegre were monitored, through the use of interviews and participant observation. It was possible to understand the complex interplay of adhesion and resistance to the heteronormative conjugal model, producing a strong agonistic tension. Two elements in the strategies of alliance between these couples could be observed. A circularity of attributes of masculinity and femininity between transvestites and their husbands, and a set of dispositions that order the sexual life.
\end{abstract}

Key-words: transvestite, conjugality, gender relations, sexuality, masculinity. 


\section{Quién ama sufre. Quién sufre lucha. Quién pelea gana. La relación} conyugal entre travestis $\gamma$ sus maridos

\section{Resumen}

La investigación se desarrolló entre los años 2009 a 2011. Su objetivo es saber cómo construir una relación conyugal entre los travestis y sus maridos. Durante dos años se ha establecido un sistema de seguimiento de tres parejas que viven en el área metropolitana de Porto Alegre, que incluye entrevistas y observación participante. Es posible entender la compleja interacción de adherencia y resistencia al modelo conyugal heteronormativo, produciendo una tensión agonística fuerte. Dos elementos se destacan en las estrategias de alianza entre estas parejas. Una circularidad de los atributos de la masculinidad y la feminidad entre los travestis y sus esposos; y un conjunto de disposiciones que ordenan la vida sexual: reificar las expectativas tradicionales de género y evitar actuaciones que pueden recordar la relación con su prostitución travesti clientes.

Palabras-clave: travestis; relaciones conyugales; relaciones de género; sexualidad, masculinidad.

Data de recebimento do artigo: 24/04/2012

Data de aprovação do artigo: 20/07/2012 